\title{
COMPARING THE PERFORMANCE OF TWO INDUSTRIES DURING THE CRISIS
}

\author{
Marija Kastelan Mrak, Danijela Sokolic* and Nenad Vretenar \\ Faculty of Economics, University of Rijeka, Rijeka, The Republic of Croatia
}

Industries create specific business settings that exert a backward influence on industry prospects. In this paper, the manner in which two industries - the construction industry and the food and beverage processing industry - have behaved during a crisis period is examined and compared. First, the performance indicators available from statistic sources are compared; then, the panel data of the two subsamples of the largest Croatian firms in terms of capital and employment related to construction and food processing in the period 2005-2014 are subjected to comparison. The provided data demonstrate that the five largest business firms in the two industries have a tendency to employ different business behaviors specific to the industry they are part of. The basic idea behind this research was that industry characteristics are created by individual business firms through their adjusting their behavior, i.e. strategies, organizational design and operation models to perceived industry settings. So, in the longer time period, depending on resource availability at the firm level and the market opportunities in the industry, a dominant pattern of the business model will evolve. The research showed differences in the rate of the activity and business demography during the observed period. There is also evidence of different business models being employed in construction and food processing. However, at this stage of our research, we have not been able to establish a relationship between the business model employed and the firm's or industry performance.

Keywords: industry behavior, performance, financial crisis 2008, business models, ownership control versus contractual networks

JEL Classification: L11, L24, L25, L66, L74

\section{INTRODUCTION}

The study of industrial organization is based on the premise that a firm's behavior and performance are strongly dependent on its operating context, or more precisely on its industrial settings. Historically,

\footnotetext{
* Correspondence to: D. Sokolic, Faculty of Economics, University of Rijeka, I. Filipovića 4, 51000 Rijeka, Croatia; e-mail: dsokolic@efri.hr
}

the issue that received the most attention has been industry structure, defined as industry concentration and measured by the "m-firm seller concentration ratio and the Herfindal index" (Martin, 1988, 7). However, towards more recent times, industry features have been described by more and more attributes. On the one hand, more complex behavioral processes, such as innovation and marketing efforts, representing the aspects of an individual firm's strategic behavior, have 
been added into the picture. On the other, an emphasis has been placed on the collective forces dominantly outside the influence of single firms; those would be called situational factors, representing the influence of the policy and regulation, the rate of technological development, cross-industry influences, economic trends (effecting aggregate demand or aggregate investments) and so forth.

In this paper, we try to look at both sides: businesses' strategic behavior and broader environmental circumstances. However, due to our limited resources, wehave reduced the model complexity by concentrating on the three specific firm-level descriptors (technology, the size and financial performance) and one industrylevel indicator, which is here used as a composite industry descriptor (Figure 1).

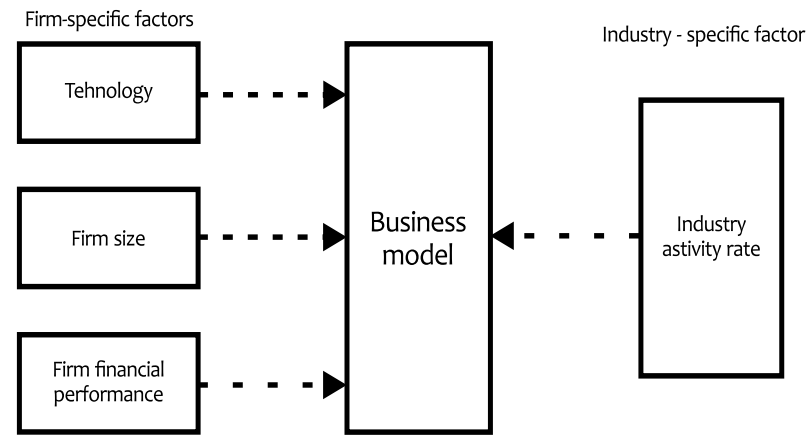

Figure 1 The Conceptual Model

Source: Authors

The business model performs the function of the focal point in which both individual (the firm's) and industry-wide influences are reflected.

The paper is structured as follows: After the Introduction, the two business models are defined and their main features are described (the first characterized mainly by ownership control and the second being seen as a model depending on contractual relations and incentive alignments). Next, some statistics on the general trends in both industries are provided, after which our observations made of the firms in our sample are presented. Finally, the research results and the limitations are given. The paper ends with a discussion about our findings.

\section{UNDERLYING THEORY, BASIC CONCEPTS AND IDEAS}

The conceptualizing and designing of business models had been the central issue in organization theory for more than a century. However, once the main challenges were no longer constricted to internal command mechanisms (the division of labor, building hierarchies and mapping process flows), the organizational design shifted attention towards the business models whose architectures implied constructing a complex mechanism of network relationships with compatible business partners.

Economic approaches to organization theory mainly address the issues of hierarchical vs network (complex market) structures, using the notion of incomplete contracts present in transaction costs and agency theories. Practitioners often speak about these phenomena in terms of business growth patterns, suggesting that there are the alternatives to organic growth that do not exclusively imply growth through M \& As. Consequently, from the 1990s onwards, attention has been drawn to the business models conceptualized as long-term contractual relationships.

The empirical evidence for the performance of the distinct types of business models is still building up. One of the questions we would like to raise is how these, presumably new, business models fare in the recent recession times.

As noted by M. G. Colombo and M. Delmastro (2008), over the past three decades, researchers have been interested in various features of organizational design; however, the employment of different research tools and a broad range of perspectives, "as diverse as management, organization science, industrial economics, business history, personnel economics, and sociology", has made this literature very fragmented.

Similarly, the term "business model“ may have many applications. Borrowing a little from several approaches, we define a business model as a specific formal organizational arrangement establishing the lines of coordination and the spread of resources and activities. 
In the strategic management literature, it could indicate a bundle of activities and resources providing for a competitive advantage (a business model designates the vertical and the horizontal spreads of technologically and/or market related businesses). In the transaction costs approach, it would designate a governance mechanism (whether a market, a contract or an administrative hierarchy is used for getting access to specific resources/inputs). In the transaction costs' perspective, technologically induced savings are present due to scale economies; but in addition, transaction costs, as the costs of depending on markets to acquire the needed inputs, are also taken into consideration. So, the motives for establishing the boundaries of a firm will be dependent on both technical and market factors. In other words, the "measure" of the size of the firm would be represented by the number of transactions internalized in it, as suggested by R. Coase (1937). Tying in with R. Coase's ideas, O. E. Williamson $(1975 ; 1985)$ specified the criteria which make transactions suitable for internalization by developing the framework for the assessment of the individual cost-effectiveness of specific organizations. The agency approach would imply that it is primarily a mechanism for allocating residual control and lowering agency costs (the alternatives being the legal forms of business establishment, such as corporations as opposed to partnerships, and eventually capital structures/debt versus equity). The aforementioned descriptions are consistent with H. E. Aldrich's (2008, 28) definition of the Organizational Forms made up of the specific configurations of goals, boundaries and activities, demonstrating their efficiency through surviving, i.e. being selected by environmental criteria.

All of the above approaches bear an implication that there is a possibility of making a more or less deliberate choice among alternative models defined by theory. Second, approaches suggest the idea that based on the strategic considerations of a specific company one model is superior in its performance in comparison with an alternative model.

It is interesting to note that the historical perspective is very important in understanding what the dominant theory at any historical moment identifies as organizational alternatives: be it mass-process production versus artisanal production; internal command chains and functional versus line hierarchies; unitary versus diversified organizations, or be a legal/ institutional arrangement, where compact corporate forms are compared to more dissolved network arrangements. Also, once theory has specified the "alternatives", practical business thinking at the firm level will often devise firm-specific business models by balancing the trade-offs of theoretical extremes. That is precisely why it is hard to empirically prove the economic dominance of one model against another.

Another important point is that choices are made at the firm level. Based on the idea of path dependency, a business model designates a firm-specific organizational arrangement that reflects the past efforts of strategic adjustment. The financial success of a business model is a result of the interaction between the business model and its environment (Pfeffer \& Salancik, 2003). Furthermore, according to both, the Structure-Conduct-Performance (S-C-P) and its countering Chicago School Paradigm (Martin, 1988), a financial success may be expected to be mostly a result of the market structure and technology. A number of authors researching the link between organizational structures, or firm boundaries, depending on the underlying theoretical context, indicate that defining the relationship of the business model design is a permanent and pervasive research problem. (Aldrich \& Herker, 1977; Galbreath \& Galvin, 2008; Zott \& Amit, 2010; Tran \& Tian, 2013). To conclude, as implied by H. Demsetz $(1997,41)$, there is a connection between control, on the one hand, and wealth distribution and institutional design, on the other.

On the other hand, we suppose that firms operating under similar circumstances would be likely to develop similar business models. Were it the case, we could look for an industry specific business model evolving as a response to industry-specific factors. The particular historical configuration of events and interpretations given to these events would allow us to construct a list of quantitative measures for a particular industry, in a certain location within a certain time frame.

The next step is the establishing of a theory to explain the distinctions between the opposed business models. Influenced by M. Best's (1990) explanation of the superiority of networks in the unstable business 
environment, we chose our two theoretical business models to be:

- the corporate model (the centralized hierarchical institution; control and allocation primarily by establishing ownership)

- the network model (legally independent companies working temporarily on joint projects; mutual controls established through contract relations).

The distinction is relevant and deserves an empirical proof.

That theoretical distinctions are always raised in order to stress the point should be taken into consideration; real-world differences may be less pronounced. In fact, "the corporate model" (i.e. the hierarchy) can also establish relatively stable ties with suppliers and distribution channels, as in the case of food and beverages manufacturing. Essentially, the main difference between the network model and the corporation model is that in the network model there is but one-term project activity. Each project participant invests and recovers his investments relatively autonomously; if potential partners, such as subcontractors, are available, partners in the project are not expected to worry too much for the future prospects of ex-partners. The corporate model will make decisions at the firm level and distribute investments according to the centralized logic of strategic growth, at least when it comes to „internal fractions" (business departments, subsidiaries and the like). Eventually, if the supplier and distributor markets are concentrated and hold-up is likely to occur, they will try to establish ownership controls over the problematic stage in the business chain.

So, if the role of smaller firms in relatively long-term patterns of cooperation were to be specified, then small firms would be those sacrificed in order to keep the large firm/partner stable. Consequently, the larger are more likely to survive. According to H. E. Aldrich (2008, 23), the point is that larger firms often do not „....if ever, 'fail'" (in the sense of going out of business). Instead, if they disappear, it is for the reason of a takeover or a merger with another firm. The point is further explained by R. T. Averitt's (1968) concept of „center firms" (as opposed to "periphery firms“). According to him, "center firms" are those which exhibit market dominance, robust cash-flows and excellent credit and when their structure is concerned, they are diversified; they have decentralized operations and serve a broad range of markets, including international.

„Through competition 'virtual organizations' networked or transitory organizations where people come together temporarily to complete a task, then separate to pursue their individual specialties - are changing the structure of the traditionally, bureaucratic organization and contributing to its shrinkage" (Jensen, 2000, 27).

At the beginning of this millennium, while introducing his elaboration of agency theory and its contribution to understanding organizational forms, M. C. Jensen $(2000,2)$ states that

„Proof of the efficiency of the corporate organizational form shows dramatically in market performance... The dominance of the corporate form of organization in large-scale, non-financial activities indicates that it is winning in this competition. Yet, in spite of this relative success it is clear from the evidence of the last twentyfive years that the corporation has failed in many ways as an organizing device".

The corporate model would resemble hierarchies, as described by O. E. Williamson $(1995,228)$, and the network model would be closer to a looser market model. O. E. Williamson also implies that it is worthy to compare the performance of distinct organization models by noting that:

„The ideal organization adapts quickly and efficaciously to disturbances of all kinds, but actual organizations experience trade-offs. Thus whereas more decentralized forms of organizations (e.g. markets) support high-powered incentives and display outstanding adaptive properties to disturbances of an autonomous kind, they are poorly suited in cooperative adaptation respects. Hierarchy, by contrast, has weaker incentives and is comparatively worse at autonomous adaptation but is comparatively better in cooperative adaptation respects".

The network would be a model of „multiorganizational aggregate" (Aldrich, 2008, 323), a new organizational form with "loosely coupled, hierarchically differentiated relations, integrated by 
the actions of linking pin-organizations, and probably rather unstable" that could possibly demonstrate some superiority; he, however, also notes that the existing research into the topic is inconclusive and highly speculative. H. E. Aldrich $(2008,349)$ is pointing out the fact that researchers often speculate about the behavioral consequences of the interorganizational networks of the economic interest, whereas such a behavior still needs to be documented. We could also count on an explanation of the reason for the expected superiority of one model over the other.

The advantage of corporations over network arrangements is stronger, more reliable control. According to O. Hart (1995, 23-30),

\begin{abstract}
„In reality, contracts are not comprehensive and are revised and renegotiated over time...As a result of contracting costs, the parties will write a contract that is incomplete. That is, the contract will contain gaps and missing provisions...ownership is a source of power when contracts are incomplete... that is, the owner of an asset has residual control rights over that asset to decide all usages of the asset in any way not inconsistent with the prior contracts".
\end{abstract}

On the other hand, M. Best (1990, 258-263), however referring primarily to global corporations and global networks, even though the point made also concerns groups of smaller firms in industrial districts and supply chains on smaller-scale markets, points to the "limits to expansion by direct production and ownership", by corporations in establishing owned divisions and subsidiaries. He suggests that instead of the „Big Business" model, „networking in the form of international consortia, cross-licensing and jointventures agreements allows firms to share marketing, distribution, $R \& D$, and even production facilities without investing directly...". While the advantages of large corporations are access to financial resources, internalized support activities and strategic planning for joint development, the advantage of networks would be lower investments for a larger reach of activities and clearly flexibility.

A period of crisis, from 2008 onwards, would therefore represent a perfect setting for demonstrating empirical evidence that networks do adapt faster, stand a better chance to survive and keep up performance even in times of hardship.

\section{RESEARCH DESIGN AND FINDINGS}

The empirical part of the paper is based on the examination of the performance of the two industries during the past decade. The last 10-15 years are an ideal scenario in which to observe the performance since it consists of a period of prosperity and expansion (2005-2008) and a period of instabilities and business contraction (after 2008).

We opted for conducting our research into the construction industry and the food manufacturing industry. Also, taking advantage of the fact that the world economy has recently been undergoing severe economic crises, we were interested in seeing whether particular business models are better adaptable than others, i.e. whether they are more capable of surviving, or at least stabilizing the business activity and keeping losses down during economic downturns.

In the research, various sources of data were used, including the panel data. In order to alleviate the interfering impact of the factors related to countryspecific conditions, our focus is on the companies pertaining to a single national economy (by doing so, we hope to eliminate the impact of macroeconomic conditions and government policies). The companies included in the research belong to the two industries: the food and beverage industry, on the one hand, and the construction and civil engineering industry, on the other. Both industries are characterized by distinguished national importance in terms of employment, value added and exports, but show different growth models, and, as we expect, they will show different capability in adapting to crisis.

We extracted data on a sample of 170 firms over a nineyear period, from 2005 to 2013, which are available in the Amadeus database (The Bureau van Dijk Database, BvD, 2010). The variables were chosen to reflect a company's past strategic choices, as well as the influence of environmental circumstances. 
Some Statistical Evidence for Industry Behavior and Performance During the Crisis

The period since 2008 has been the period of lowering the economic activity (Tables 1, 2 and 3). The GDP fell sharply in 2009, and the economy has not recovered yet. Demand also fell, but domestic demand has been falling at a higher rate only in the past three years, while the largest drop in exports occurred in 2009, since when exports have been recovering. It is indicative that construction works have been falling continuously and ever more rapidly, whereas the production of consumer, non-durable products has had its ups and downs, but the drop has never been as sharp as in construction.

According to the indicators drawn by the Croatian Bureau of Statistics (CBS), the business activity level has started continuously slowing down after 2008. The drop was felt heavier in the construction industry than in the food and beverages industry.

Table 1 Some economic indicators for Croatia $(2010=100)$

\begin{tabular}{l|ccccccccc}
\hline & 2005 & 2006 & 2007 & 2008 & 2009 & 2011 & 2012 & 2013 & 2014 \\
\hline Real GDP growth rates & -0.7 & 3.6 & 6.6 & 6.6 & 0.8 & -0.7 & -3.1 & -4 & -3.6 \\
Personal consumption & 0.3 & 4.5 & 9.6 & 6.3 & -0.6 & 0.5 & -3.3 & -4.7 & -5 \\
\hline
\end{tabular}

Source: Croatian National Bank

Table 2 Some economic indicators for Croatia (seasonally adjusted, the index)

\begin{tabular}{l|cccccccccc}
\hline & 2005 & 2006 & 2007 & 2008 & 2009 & 2010 & 2011 & 2012 & 2013 & 2014 \\
\hline $\begin{array}{l}\text { Exports of goods and } \\
\text { services }\end{array}$ & 1.7 & 8.6 & 6.7 & 5.1 & -7.9 & 5.1 & 0.4 & 1.6 & 8.3 & 12.8 \\
$\begin{array}{l}\text { Gross fixed capital for- } \\
\text { mation }\end{array}$ & 11.3 & 20.5 & 25.8 & 30.3 & 22.6 & -1.5 & -3.2 & -6.0 & -8.7 & -12 \\
$\begin{array}{l}\text { Industrial production } \\
\text { of non-durables (Dec.) }\end{array}$ & 5.1 & 4.3 & 6.9 & 8.9 & -1.9 & -0.6 & 4.9 & -7.3 & -4.0 & 2.6 \\
$\begin{array}{l}\text { Total volume of con- } \\
\text { struction works (Dec.) }\end{array}$ & 7.3 & 14.7 & 16.5 & -2.6 & -4.3 & -4.2 & -4.3 & 17.8 & -17.9 & -15.7 \\
\hline
\end{tabular}

Source: Croatian Bureau of Statistics

Table 4 allows us to perceive how relatively small the Croatian economy is compared to the economies of other European countries (the bolded row). Unfortunately, we could not obtain data that would show whether the Croatian population of firms in the observed industries has been increasing or decreasing since 2008. Yet, we did obtain the figures on firms demography from the panel data (the numbers are presented in the next section of this paper) that demonstrate that, although small in size, in comparison with the majority of the European economies, the Croatian food and beverages manufacturing industry and its construction industry demonstrate downturn trends similar to those in the other European countries.

In conclusion, it is possible to see that the general trend has been decreasing, especially for the countries from Southeast Europe (SEE), often used for comparisons with Croatia, so both the Croatian construction industry and the food and beverages industry are likely to have been under stress during the past years of recession. Also, by comparing the figures, it appears that, on average, firms in the food and beverage industry have been more resistant to crises, which could be due to the 
Table 3 The index of construction works, the manufacturing of food and beverages, seasonally adjusted

\begin{tabular}{|c|c|c|c|c|c|c|c|c|c|}
\hline Industry & 2005 & 2006 & 2007 & 2008 & 2009 & 2010 & 2011 & 2012 & 2013 \\
\hline Construction (June)* & 101.2 & 111.1 & $113 \cdot 3$ & 128.1 & 120.0 & 97.8 & 89.5 & 81.7 & $77 \cdot 9$ \\
\hline $\begin{array}{l}\text { Food products manufac- } \\
\text { turing }\end{array}$ & 102.9 & 101.9 & 104.1 & 99.4 & 98 & 100.2 & 106.6 & 101.7 & $95 \cdot 5$ \\
\hline Production of beverages & 103.6 & 98.2 & 113.2 & 115 & 100.7 & 96.8 & 96.2 & 86 & 109.8 \\
\hline
\end{tabular}

* The value of the construction works relates to June, the month that on average demonstrated the highest sectoral activity.

Source: Croatian Bureau of Statistics

Table 4 Active enterprises with more than 10 employees (the number)

\begin{tabular}{|c|c|c|c|c|c|c|c|c|c|c|}
\hline \multirow[b]{2}{*}{ Country } & \multicolumn{5}{|c|}{ Construction } & \multicolumn{5}{|c|}{ Manufacturing of food, beverages and tobacco } \\
\hline & 2008 & 2009 & 2010 & 2011 & 2012 & 2008 & 2009 & 2010 & 2011 & 2012 \\
\hline EU (28) & : & : & : & : & 198,702 & : & : & : & : & 58,310 \\
\hline $\mathrm{EU}(27)$ & $:$ & $:$ & : & 206,396 & $:$ & : & : & : & 58,645 & : \\
\hline Belgium & 4,252 & 4,202 & 4,230 & 4,379 & 4,320 & 1,266 & 1,257 & 1,251 & 1,253 & 1,210 \\
\hline Bulgaria & 4,872 & 4,452 & 3,416 & 3,050 & 2,877 & 1,668 & 1,722 & 1,676 & 1,650 & 1,557 \\
\hline Czech R. & 5,882 & 5,945 & 5,804 & 5,591 & 5,474 & 1,652 & 1,670 & 1,613 & 1,562 & 1,532 \\
\hline Denmark & $:$ & 2,805 & 2,484 & 2,543 & 2,500 & $:$ & 483 & 439 & 434 & 423 \\
\hline Germany & 33,651 & 34,190 & 34,832 & 35,923 & 36,339 & 10,378 & 10,289 & 10,172 & 10,025 & 9,860 \\
\hline Estonia & 1,403 & 1,067 & 770 & 799 & 873 & 220 & 206 & 193 & 189 & 201 \\
\hline Ireland & 2,874 & 1,716 & 1,285 & 1,077 & 920 & 455 & 438 & 451 & 443 & 446 \\
\hline Croatia & $:$ & : & : & : & 1,660 & : & : & : & : & 819 \\
\hline Italy & 27,057 & 24,636 & 22,911 & 21,065 & 18,963 & 5,952 & 5,754 & 5,816 & 6,076 & 6,123 \\
\hline Latvia & 1,896 & 1,257 & 1,086 & 1,204 & 1,236 & 0 & 0 & 352 & 350 & 329 \\
\hline Lithuania & 2,926 & 2,240 & 1,929 & 2,179 & 2,331 & 540 & 525 & 538 & 526 & 534 \\
\hline Hungary & 4,092 & 3,459 & 3,446 & 3,293 & 3,114 & 1,561 & 1,504 & 1,547 & 1,523 & 1,493 \\
\hline Austria & 5,523 & 5,528 & 5,583 & 5,700 & 5,748 & 1,367 & 1,361 & 1,380 & 1,382 & 1,421 \\
\hline Poland & 12,097 & 12,339 & 13,272 & 14,476 & 13,880 & 6,215 & 6,301 & 6,487 & 6,353 & 5,911 \\
\hline Portugal & 9,683 & 8,687 & 7,872 & 7,023 & 5,560 & 2,246 & 2,227 & 2,250 & 2,213 & 2,048 \\
\hline Romania & 8,661 & 8,055 & 6,956 & 7,934 & 7,759 & 2,979 & 3,003 & 2,933 & 2,985 & 2,897 \\
\hline Slovenia & 1,470 & 1,431 & 1,269 & 1,134 & 1,012 & 214 & 209 & 211 & 191 & 201 \\
\hline Slovakia & 2,945 & 2,055 & 1,269 & 1,660 & 1,541 & 844 & 659 & 498 & 570 & 553 \\
\hline SUM & 129,284 & 124,064 & 118,414 & 119,030 & 116,107 & 37,557 & 37,608 & 37,807 & 37,725 & 37,558 \\
\hline
\end{tabular}

Source: Eurostat 
lower price elasticity of demand for food and beverages, as well as to the industry and firm-specific factors.

\section{Cross-industry Variations According to the Panel Data Sample}

In order to study the differences of the prospects of the industry sector, we extracted data for all Croatian companies in the food and beverages manufacturing industry and the construction industry, which makes a total of 80 and 91 companies, respectively. The data were extracted for the companies considered as large according to the Croatian standards, i.e. those employing 100 or more employees. The most interesting observation was that, once the industry had been analyzed on a sample of larger firms (the statistical data reports on all firms employing 10 or more employees), a downturn in behavior (outlays), the activity level (the cash flow) and performance (operating revenues) were less pronounced.

Table 5 summarizes the descriptive statistics on our sample of firms. As can be seen from Table 5, the subsamples themselves are very heterogeneous in almost all categories of indicators. In fact, standard deviations often exceed average values.

A suggestive observation concerning the above sample, consistent with the theory that larger firms

Table 5 The comparative indicators of the subsamples 2013

\begin{tabular}{|c|c|c|c|c|c|c|}
\hline \multirow{2}{*}{$\begin{array}{l}\text { Industry } \\
\text { Financial values } \\
\text { (in 000) }\end{array}$} & \multicolumn{3}{|c|}{$\begin{array}{l}\text { Manufacturing of food and beverages } \\
(\mathrm{N}=80)\end{array}$} & \multicolumn{3}{|c|}{$\begin{array}{c}\text { Construction, excluding } \\
(\mathrm{N}=91)\end{array}$} \\
\hline & mean & sd & $\max -\min$ & mean & sd & $\max -\min$ \\
\hline Operating Revenues & 47,611 & 66,605 & $\begin{array}{r}360,346 \\
2,404\end{array}$ & $\begin{array}{r}23,114 \\
(21,086)\end{array}$ & $\begin{array}{r}33,001 \\
(27,462)\end{array}$ & $\begin{array}{r}199,937 \\
(117,091) \\
0\end{array}$ \\
\hline Total assets & 52,619 & 70,478 & $\begin{array}{r}313,521 \\
1,215\end{array}$ & $\begin{array}{l}195,288 * \\
(29,947)\end{array}$ & $\begin{array}{r}1,138.950 * \\
(91,320)\end{array}$ & $\begin{array}{r}9,182,520 * \\
(825,243) \\
9,128\end{array}$ \\
\hline $\begin{array}{l}\text { No. of employees } \\
\text { (absolute no.) }\end{array}$ & 409 & 466 & $\begin{array}{r}3308 \\
100\end{array}$ & $\begin{array}{r}278 \\
(266)\end{array}$ & $\begin{array}{r}277 \\
(259)\end{array}$ & $\begin{array}{r}1,319 \\
(1,319) \\
100\end{array}$ \\
\hline Cash flow & 4,092 & 8,608 & $\begin{array}{l}53,619 \\
-9,010\end{array}$ & $\begin{array}{r}2,148 \\
(1,016)\end{array}$ & $\begin{array}{r}11,551 \\
(5,060)\end{array}$ & $\begin{array}{r}98,690 \\
(30,166) \\
-20,783\end{array}$ \\
\hline Capital & 12,777 & 21,657 & $\begin{array}{r}141,651 \\
0\end{array}$ & $\begin{array}{r}125,087^{*} \\
(6,805)\end{array}$ & $\begin{array}{l}881,542 * \\
(30,065)\end{array}$ & $\begin{array}{r}7,958,243 * \\
(281,211) \\
3\end{array}$ \\
\hline Shareholder funds & 27,011 & 44,073 & $\begin{array}{r}239,770 \\
-1,827\end{array}$ & $\begin{array}{r}119,500 * \\
(1,077)\end{array}$ & $\begin{array}{r}882,391^{*} \\
(31.356)\end{array}$ & $\begin{array}{r}7,958,187^{*} \\
(44,412) \\
-8,387\end{array}$ \\
\hline Profit margin (\%) & 1.99 & 8.54 & $\begin{array}{l}28.69 \\
-31.41\end{array}$ & $\begin{array}{r}-1,51 \\
(1.78)\end{array}$ & $\begin{array}{r}16.42 \\
(16.43)\end{array}$ & $\begin{array}{r}23.21 \\
(23.21) \\
-133.98 * * \\
(-85.79)\end{array}$ \\
\hline No. of subsidiaries & 2.33 & 4.25 & $\begin{array}{r}25 \\
0\end{array}$ & $\begin{array}{r}2.31 \\
(2.22)\end{array}$ & $\begin{array}{r}4.47 \\
(4.46)\end{array}$ & $\begin{array}{r}23 \\
0\end{array}$ \\
\hline
\end{tabular}

* All 91 companies in the construction industry in Croatia are included in the sample. However, for the sake of comparison, the indicators for all the construction companies, with the exception of the two largest companies in terms of assets are given in brackets (these two are the government-owned Croatian Highways and Croatian Roads and the value of the roads is accounted for in their portfolio). The value of approximately 16 trillion EUR accounts for almost $85 \%$ of all the assets and is therefore excluded from the calculation in brackets.

** The national companies operating roads and highways are also responsible for a sizeable loss. This is one of the supposed reasons for the actual government to try arranging for a concession agreement with potentially interested private sector investors.

Source: Authors, based on the data in the Amadeus database 
survive at the expense of smaller ones, is that very few companies went out of business during the observed period. In fact, only one construction firm, active in 2005, was inactive (had no operating revenues) in 2013.

In both industries, only one construction firm went out of business. Looking at the industry averages in Figure 1 (the sample firms only), in spite of the crisis, the average number of the employees in the selected industries remained almost the same in the 2005-

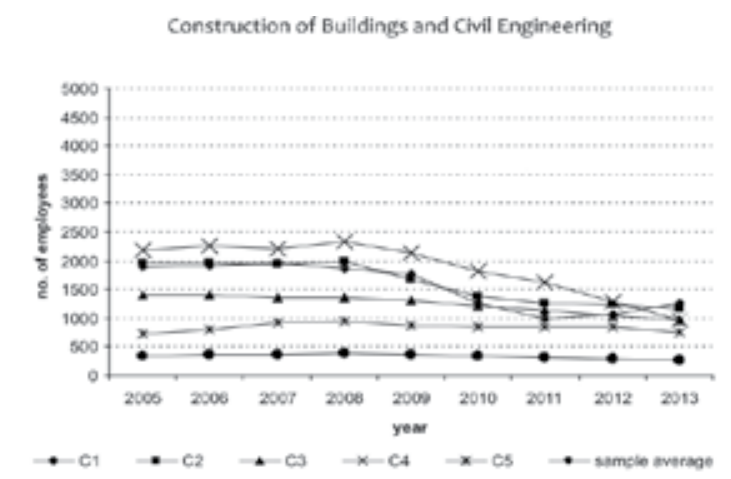

2013 period. Still, by looking at the figures for the five largest firms in both industries, the very largest firms by the number of employees were those with more pronounced layoffs.

Another set of observations concern changes in some basic indicators of business trends: the total assets and operating revenues. Figure 2 again is indicative of the figures for the five largest companies (the size expressed in terms of the number of employees) for both industries, plus the sample average values.

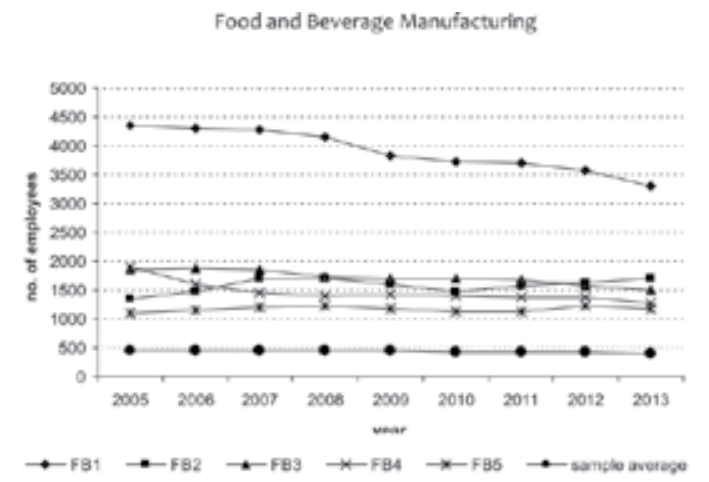

Figure 1 The comparison of the industry average and the five largest companies by the number of employees Source: Authors, based on the data in the Amadeus database
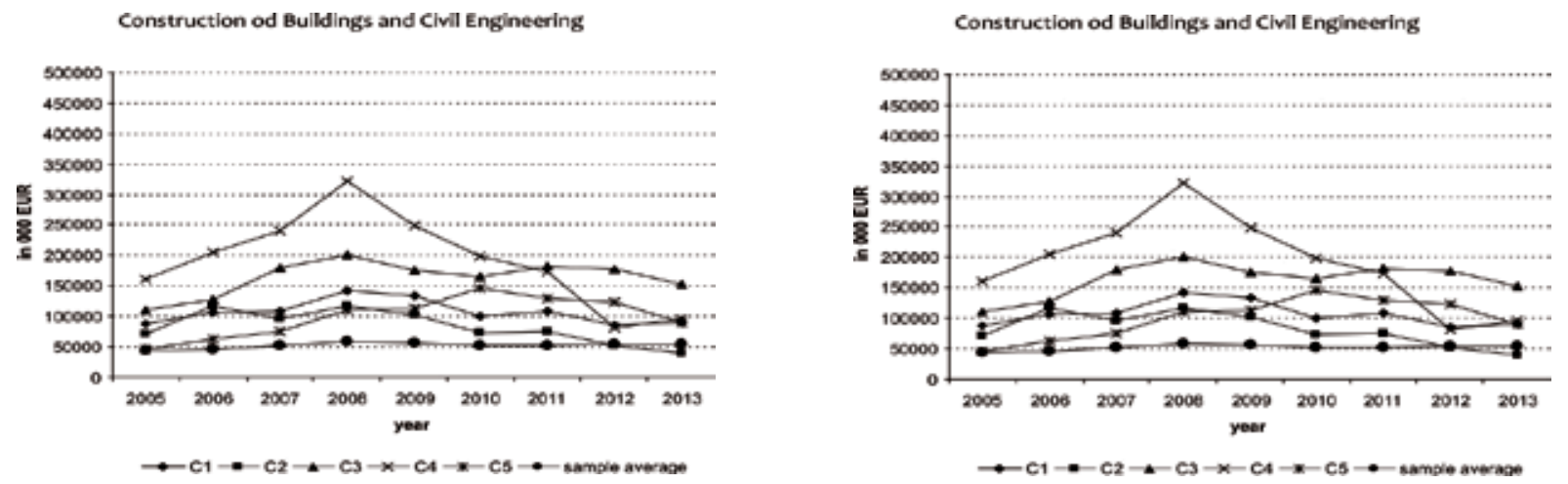

Figure 2 The comparison of the industry average and the five largest companies by the total assets (in 000 EUR)

Source: Authors, based on the data in the Amadeus database

It can be seen in Figure 3 that the operating revenues suffered a more severe fall in construction, whereas the manufacturing of food and beverages showed almost no decline. It is also interesting that the five largest construction firms (the government-operated roads and highroads excluded!) had a substantially higher decline in the operating revenues compared to the rest of the firms in the industry sample.Once again, it is indicative that the industry averages for the firms in the panel (contrary to the expectations, according to the statistical data on the volume of the activity, Tables 1 and 2) did not change throughout the period in 
spite of the crisis. We did not look into the individual performance of the smaller firms in the sample, but it will definitely be a challenge to gain an insight into whether their assets and revenues, and perhaps even employees themselves, have been shifting among firms.

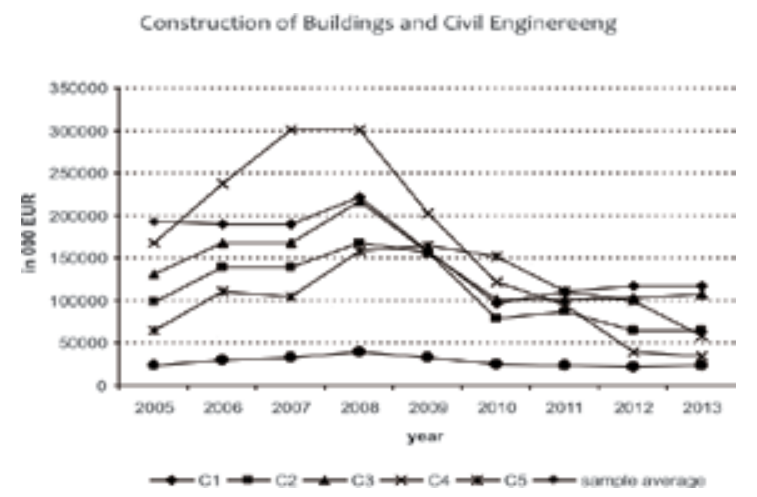

strategic alliances and other types of networks. Most constructors offer a full service ranging from green field to finalized turnkey projects. However, constructing a building consists of the work conducted by a variety of tasks requiring specialized

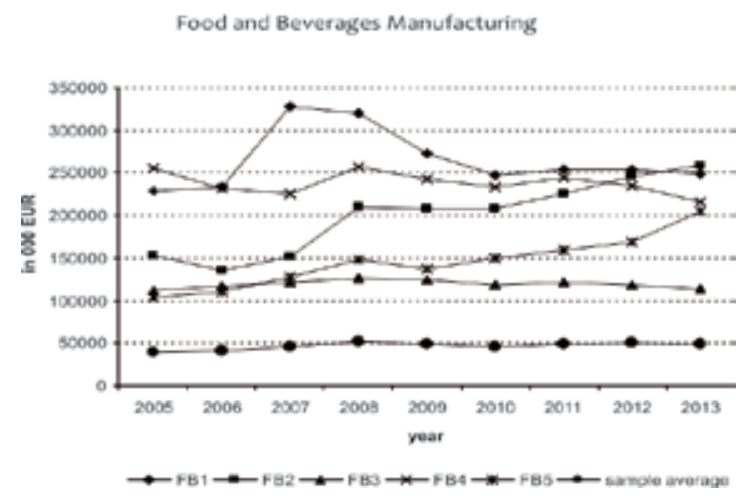

Figure 3 The comparison of the industry average and the five largest companies by the operating revenues (in $000 \mathrm{EUR}$ ) Source: Authors, based on the data in the Amadeus database

\section{SOME OBSERVATIONS OF THE} INDUSTRY-SPECIFIC ORGANIZATIONAL ARRANGEMENTS

The food and beverage industry ${ }^{1}$ in Croatia is quite heterogeneous in its nature; companies range from small locally based processing firms to large multinational corporations with integrated value chains (from farms to wholesale and retail stores) or diversified into different industries; the ownership structure of those companies varies from state- to privately-owned companies, with few strategic owners or many small stockholders (both/either natural persons and/or legal entities). Even though a variety exists, the industry is highly concentrated, which implies that few large companies hold a large portion of market share. At the same time, the industry is also highly vertically coordinated and integrated through both ownership and contracts. Still, compared to construction, ownership is more pronounced.

Construction and civil engineering are considered to be highly networked industries, namely an industry requiring a high variety of tasks. Firms operating in this sector are engaged in numerous co-operations, (but not rare to find) skills and technology. For instance, a typical construction building requires setting up electrical, plumbing and heating/cooling infrastructures, only to be followed by laying parquetry, ceramics, inside and outside doors and windows, finishing and painting and so forth. All those tasks are usually performed by specialists, and even though every building includes this kind of work, the largest number of constructing firms opt for the regulation of relations with them through revolving contracts rather than employment ones. Employing a specialist whose skills are specific but not rare is an option only when there is a constant need for his/her services and the internalization of his/her services is more cost-effective than contracting his/her services.

Unfortunately, for the purpose of research, the relations relying on contracts are much harder to trace. The tracing can be done by accounting forensics, tracing transactions, auditing and other diligence methods applied to every specific case, but those methods are unavailable to academic researchers. Therefore, we rely on mainly anecdotal evidence for the support of the commonly accepted idea that construction and civil engineering are a fair representative of the network business model. 
Here are some arguments we find convincing. First, more than $1000 \mathrm{~km}$ of highways have been built in Croatia in the last 15 years. Many Croatian civil engineering firms have participated in this big investment cycle. The biggest ones have those that were officially given the job on auctions (often as partners in a consortium), whereas the others were included as subcontractors. As a precondition enabling them to bid for a public procurement contract, Croatia obligated the firms that offer constructing services on auctions to attach the list of future subcontractors and submit the evidence so as to prove their joint building capacities. It was also the measure that was aimed at guaranteeing the quality of the services.

The second indication of networking arrangements comes from the firms that were included in the building or reconstructing of higher value projects, such as hotels and residential buildings acting as a party to a building contract, but actually having no building capacities (equipment, building workers) of their own. The interviews conducted with several construction engineers from different firms in Croatia confirmed that most work in constructing and civil engineering is done by the joint effort of many firms, although with typically one or a few of them having a direct contract with the investor.
As can be seen from Table 6, the ownership perspective used as a weapon for establishing control is more pronounced in the firms belonging to the food and beverages industry and the consequence of it is more complex corporate group ${ }^{2}$ structures. If only the top five firms in the industry are taken into consideration (by the number of employees), it becomes obvious that corporate groups are a common pattern of organization. In terms of the number of entities and technological and market differentiation scopes, extensive structures can be observed in most cases in our sample. As an illustration, the average size of the corporate group in the food and beverage industry is 126 in comparison to only 7 in the construction industry (Tables 6 and 7).

The three of the five biggest food and beverages companies have subsidiaries at more than one level, but none of the top five in construction.

Thus, it can be concluded that the food and beverage industry is highly consolidated and oligopolistic in its structure. This is consistent with the global trends observed in various studies (Bolotova, Connor \& Miller, 2007, 17-33; Fuglie, Heisey, King, Day-Rubenstein, Schimmelpfennig, Wang, Pray

Table 6 The food and beverage industry - the five largest companies in the sample, according to the number of employees

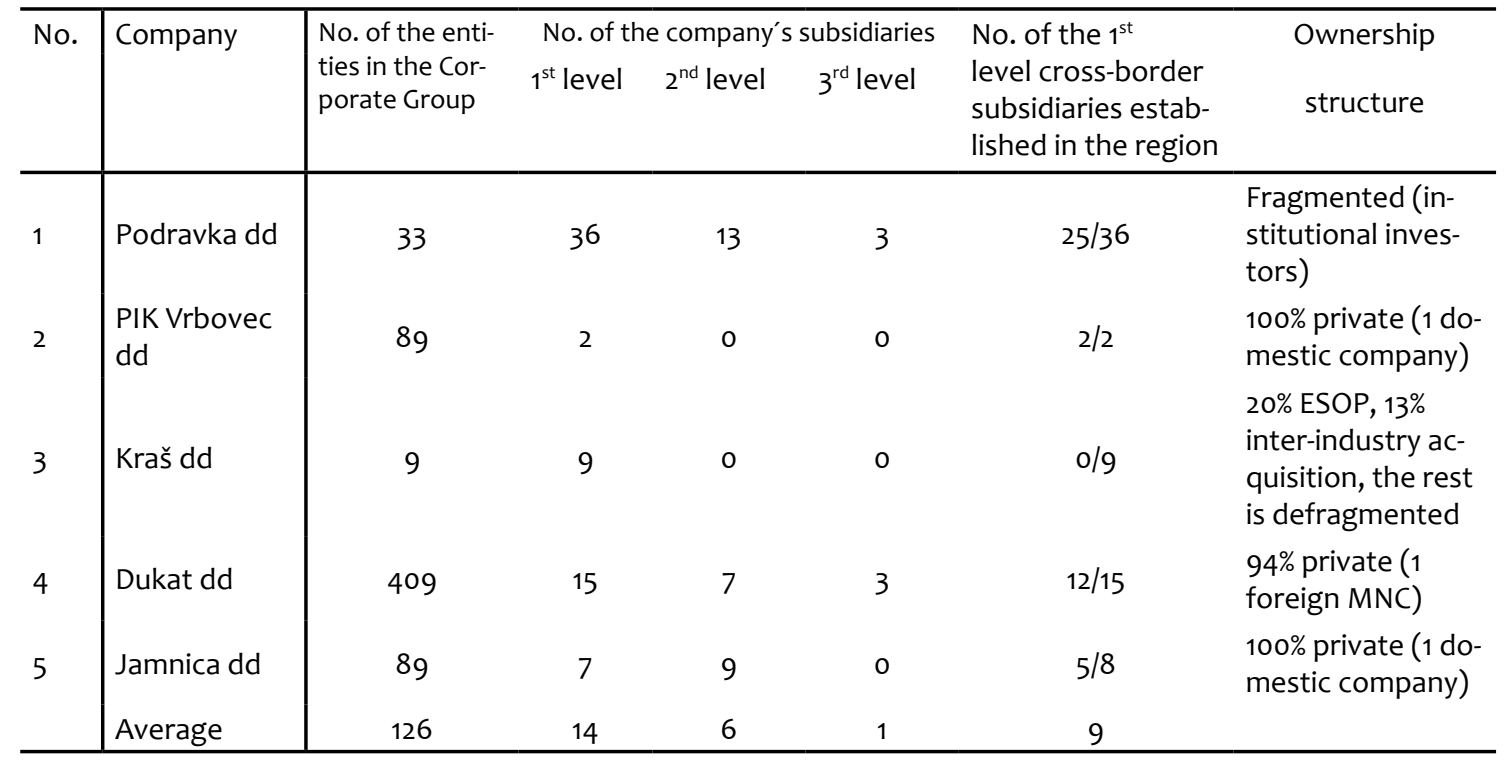


Table 7 The construction and civil engineering industry - the five largest companies in the sample, according to the number of employees

\begin{tabular}{|c|c|c|c|c|c|c|c|}
\hline \multirow[t]{2}{*}{ No. } & \multirow[t]{2}{*}{ Company } & \multirow{2}{*}{$\begin{array}{l}\text { No. of the } \\
\text { entities in } \\
\text { the Corpo- } \\
\text { rate Group }\end{array}$} & \multicolumn{3}{|c|}{$\begin{array}{c}\text { No. of subsidiaries of the com- } \\
\text { pany }\end{array}$} & \multirow{2}{*}{$\begin{array}{l}\text { No. of } 1^{\text {st }} \text { level cross- } \\
\text { border subsidiaries } \\
\text { established in the } \\
\text { region }\end{array}$} & \multirow[t]{2}{*}{ Ownership } \\
\hline & & & $1^{\text {st }}$ level & $2^{\text {nd }}$ level & $3^{\text {rd }}$ level & & \\
\hline 1 & Viadukt dd & 12 & 16 & 0 & 0 & $8 / 16$ & $\begin{array}{l}\text { Defragmented } \\
\text { (7\% self-owned, } 7 \% \\
\text { physical person, } 5 \% \\
\text { bank, etc.) }\end{array}$ \\
\hline 2 & $\begin{array}{l}\text { Hidroelektra } \\
\text { niskogradnja } \\
\text { dd }\end{array}$ & 2 & 1 & 0 & 0 & $\mathrm{o} / 1$ & $\begin{array}{l}100 \% \text { private ( } 1 \text { do- } \\
\text { mestic owner) }\end{array}$ \\
\hline 3 & Tehnika dd & 11 & 14 & 0 & 0 & $3 / 14$ & $\begin{array}{l}20 \% \text { ESOP, } 9 \% \text { bank, } \\
\text { the rest is defrag- } \\
\text { mented }\end{array}$ \\
\hline 4 & $\begin{array}{l}\text { Konstruktor - } \\
\text { inžinjering dd }\end{array}$ & 14 & 19 & 0 & 0 & $4 / 19$ & $\begin{array}{l}50.23 \% \text { private }(1 \\
\text { domestic owner) }\end{array}$ \\
\hline \multirow[t]{2}{*}{5} & $\begin{array}{l}\text { Zagorje -beton } \\
\text { dd }\end{array}$ & 16 & 14 & 0 & 0 & $8 / 14$ & $\begin{array}{l}100 \% \text { private ( } 1 \text { do- } \\
\text { mestic owner) }\end{array}$ \\
\hline & Average & 7 & 10 & 0 & 0 & 3 & \\
\hline
\end{tabular}

Source: Authors, based on the data in the Amadeus database

\& Karmarkar-Deshmukh, 2011, 113-131; Saitone \& Sexton, 2012, 2-6). These industry characteristics are very likely the product of the technologyspecific economies of scale and scope, achieved both through large processing technology systems and through the internalization of different production stages (agricultural inputs, processing, distribution, storing, packing, marketing, retailing, etc.). Again, the Croatian food and beverages industry case is consistent with the global business model, usually applied in the observed industry, which simultaneously allows high productivity levels (Gopinath, Pick \& Li, 2003, 1-21) and enables the posing of barriers to new entries with relatively high sunk costs (Paul, 2000, 217-240), giving the current players more and more market power, which ultimately leads to new acquisitions and higher levels of concentration.

The organizational differences noted among the industries relate to the terms of ownership. The business model in the food and beverages manufacturing industry is made up of companies integrated through capital (ownership stakes).The subsidiaries are often geographically spread across the region (mainly in Southeast European countries, as well as in the nearby EU countries, such as Austria, Hungary, Poland,
Czech Republic etc.). The networks employed by the construction industry were mostly established as a solution for adapting the capacity to specific project requirements. With the government acting as the top investor, political and economic factors exerted a high influence on the behavior and performance of the construction industry during the 2005-2013.

\section{CONCLUSION}

The observation of the industry acidity rates observed by using the statistical data provided by the National Statistics and Eurostat demonstrate that the construction and the food processing industries reported a drop in their activity, however with one industry suffering a steeper downturn (the construction). Also, when the construction industry is concerned, the downturn started a year later compared to the food processing industry, but lasted for a longer time.

The comparison of the behavioral and performance patterns by using another data set, the panel data, confirmed the differences between the demonstrated industry patterns. According to the panel data, 
even though industry employment-related trends demonstrate that the sample averages have remained the same, differences do appear in the operating revenues and the value of the total assets. The figures on the operating revenues are well diversified, whereas the trends regarding the total assets are almost erratic.

Moreover, it is also interesting to note that individual firms may show a substantial deviation from the average industry figures. This fact was established by looking into more detail at the largest five firms in each industry. Somewhat surprisingly, the largest firms, at least in the food processing industry, showed almost no influence of the crisis on employment, activity levels and performance.

In conclusion, this research has re-confirmed that the industrial sectors show differences in behavior and performance. Exposed to similar macroeconomic circumstances, the two industries have demonstrated different activity patterns over the same period. Still, the collected evidence revealing that some firms were able to circumvent the general declining industry trend is considered to be the main contribution of this research. The analyzed data suggest that the bigger firms were able to better adjust themselves in the period of the crisis. Also, there are some indications that the business model employed by the largest companies in the sector might have played a role in mitigating falling demand.

Further research will be needed in order to test this theory. One of the main limitations of this research was that it used the panel data and for the most part our observations may be attributed to accidental errors. Due to the restraints in time and the available data, a potentially more in-depth analysis of the differences in organizational models (strategies and the resulting organizational arrangements over a longer period of time) was constrained to a rather small subsample of companies. At this time, we did not explore the possibility of extending this research towards a regression analysis that would attempt to control factors like technology endowment, firmlevel market share, ownership stakes etc., leaving out the organizational model to be the dummy variable in the regression. Even if we took this direction, it would still be necessary to define the "organizational model" by using more attributes than just the number of related business entities and their status in terms of ownership.

\section{ENDNOTES}

Companies in the food and beverages industry produce intermediate foodstuffs or edible products for human and animal consumption. It does not include the food wholesale, retailing or service sectors (Fuglie et al, 2011). The term „manufacture“ is used in the International Standard Industrial Classification (ISIC) and North American Industry Classification System (NAICS) codes. Several ERS publications refer to ,processing“ industries.

2 A corporate group is a group of parent-subsidiary related companies operating through a common center of control. The corporate group is usually owned by a holding company or strategically the most powerful company in the group.

\section{ACKNOWLEDGMENT}

This work has been supported by the Ministry of Science, Education and Sports (Project ID: 115-1151212-2637).

\section{REFERENCES}

Aldrich, H. E. (2008). Organizations and Environments. Stanford, USA: Stanford University Press.

Aldrich, H. E., \& Herker, D. (1977). Boundary spanning roles and organization structure. The Academy of Management Review, 2(2), 217-230.

Averitt, R. T. (1968). The Dual Economy: The Dynamics of American Industry Structure. Pennsylvania, USA: W. W. Norton \& Company.

Best, M. (1990). The New Competition: Institutions of Industrial Restructuring. USA: Harvard University Press.

Bolotova, Y., Connor, J. M., \& Miller, D. J. (2007). Factors influencing the magnitude of cartel overcharges: An empirical analysis of food-industry cartels. Agribusiness, 23(1), 17-33. doi: 10.1002/agr.20111

Coase, R. (1937). The nature of the firm. Economica, 4(16), 386405. doi: 10.1111/j.1468-0335.1937.tb00002.x 
Colombo, M. G., \& Delmastro, M. (2008). The Economics of Organizational Design: Theoretical Insights and Empirical Evidence. Basingstoke, UK: Palgrave MacMillan.

Demsetz, H. (1997). The Economics of the Business Firm: Seven Critical Commentaries. Cambridge, UK: Cambridge University Press.

Fuglie, K., Heisey, P., King, J. L., Day-Rubenstein, K., Schimmelpfennig, D., Wang, S. L., Pray, C. E., \& KarmarkarDeshmukh, R., (2011). Research investments and market structure in the food processing, agricultural input, and biofuel industries worldwide. USDA-ERS Economic Research Report, 130. doi.org/10.2139/ssrn.2027051

Galbreath, J., \& Galvin, P. (2008). Firm factors, industry structure and performance variation: New empirical evidence to a classic debate. Journal of Business Research, 61(2), 109-117. doi.org/10.1016/j.jbusres.2007.06.009

Gopinath, M., Pick, D., \& Li, Y. (2003). Concentration and innovation in the U. S. food industries. Journal of Agricultural $\mathcal{E}$ Food Industrial Organization, 1(1), 1-23. doi: 10.2202/1542-0485.1028

Hart, O. (1995). Firms, Contracts and Financial Structure. Oxford, USA: Oxford University Press.

Jensen, M. C. (2000). A Theory of the Firm: Governance, residual claims, and organizational forms. Cambridge, Massachusetts, USA: Harvard University Press.

Martin, S. (1988). Industrial Economics: Economic Analysis and Public Policy. New York, NY: MacMillan Publishing.

Paul, C. J. M. (2000). Modeling and Measuring Productivity in the Agri-Food Sector: Trends, Causes and Effects. Canadian Journal of Agricultural Economics. 48(3), 217-240. doi: 10.1111/ j.1744-7976.2000.tb00277.x

Pfeffer, J., \& Salanick, G. (2003). The External Control of Organizations: A Resource Dependence Perspective. USA: Stanford University Press.

Saitone, T. L., \& Sexton, R. J. (2012). Market Structure and Competition in the US Food Industries. Implications for the 2012 Farm Bill. Retrieved April 20, 2016, from http://www.aei. org/wp-content/uploads/2012/04/-market-structure-andcompetition-in-the-us-food-industries_102234192168.pdf

Tran, Q., \& Tian, Y. (2013). Organizational structure: Influencing factors and impact on a firm. American Journal of Industrial and Business Management, 3(2), 229-236. doi: 10.4236/ ajibm.2013.32028

Zott, C., \& Amit, R. (2010). Business model design: An activity system perspective. Long Range Planning, 43(2-3), 216-226. doi: 10.1016/j.lrp.2009.07.004

Williamson, O. E. (1975). Markets and Hierarchies: Analysis and Antitrust Implications: A study in the economics of internal organization. New York, NY: The Free Press.

Williamson, O. E. (1985). The Economics Institutions of Capitalism: Firms, markets. Relational Contracting. USA: The Free Press.

Williamson, O. E. (1995). Organization Theory: from Chester Barnard to the present and Beyond. USA: Oxford University Press

Croatian Bureau of statistics. Retrieved April 21, 2016, from http:// www.dzs.hr/default_e.htm

Croatian National Bank: Main Macroeconomic Indicators (longer data series). Retrieved April 22, 2016, from http://www. hnb.hr/documents/20182/121813/e-ekonomski_indikatori. xlsx/321a6686-04d4-414e-9803-6c5e6b9d9d58

Eurostat - Your key to European statistics. Retrieved April 15, 2016, from http://ec.europa.eu/eurostat/data/database

The Bureau van Dijk Database, BvD, 2010 - Amadeus. Retrieved March 17, 2016, from http://www.bvdinfo.com/en-gb/ourproducts/company-information/international-products/ amadeus

Received on $19^{\text {th }}$ October 2016, after two revisions, accepted for publication on $26^{\text {th }}$ December 2016. 
Marija Kastelan Mrak is a Full Professor at the University of Rijeka, Faculty of Economics, Rijeka, the Republic of Croatia. She is professor of Theory of Organization, Business Organization, Operation Management and Organizational Behavior at the undergraduate, graduate, postgraduate and doctoral level.

Danijela Sokolic is an Assistant Professor at University of Rijeka, Faculty of Economics, Rijeka, the Republic of Croatia. She teaches Business Organization and Organizational Behavior at the undergraduate and graduate level.

Nenad Vretenar is an Assistant Professor at University of Rijeka, Faculty of Economics, Rijeka, the Republic of Croatia. He teaches Business Organization, Operations Management and Organization Theory at the undergraduate and graduate level.

\title{
POREĐENJE UČINAKA DVEJU INDUSTRIJA U KRIZNOM PERIODU
}

\author{
Marija Kastelan Mrak, Danijela Sokolic and Nenad Vretenar \\ Faculty of Economics, University of Rijeka, Rijeka, The Republic of Croatia
}

Industrije stvaraju specifične poslovne ambijente koji utiču na mogućnosti koje industrijama stoje na raspolaganju. $U$ ovom radu su ispitani i upoređeni načini ponašanja dveju industrija - građevinske industrije i industrije hrane i pića - u kriznom periodu. Upoređeni su, prvo, pokazatelji učinaka, dobijeni iz statističkih izvora, a, zatim, panel podaci dvaju poduzoraka najvećih preduzeća u Hrvatskoj, u pogledu kapitala i zaposlenosti, koji se odnose na građevinarstvo i preradu hrane, u periodu 2005-2014. Navedeni podaci pokazuju da je pet najvećih preduzeća u dotičnim dvema industrijama sklono primeni različitih poslovnih ponašanja, specifičnih za industriju kojoj pripadaju. Bazična ideja sprovedenog istraživanja je da karakteristike jedne industrije stvaraju individualna preduzeća kroz njihova prilagođavanja sopstvenog ponašanja, tj. strategija, organizacionog dizajna i operativnih modela postojećem ambijentu u odnosnoj industriji. Stoga će, u dužem periodu, dominantni obrazac poslovnog modela evoluirati, u zavisnosti od raspoloživosti resursa na nivou preduzeća i tržišnih prilika u dotičnoj industriji. Ovo istraživanje je pokazalo razlike u stopi aktivnosti i poslovnoj demografiji u posmatranom periodu. Takođe, postoji dokaz o tome da se u građevinarstvu i preradi hrane primenjuju različiti poslovni modeli. Međutim, u ovoj fazi istraživanja, nismo bili u prilici da uspostavimo odnos između primenjenog poslovnog modela i učinaka preduzeća ili industrije.

Ključne reči: ponašanje industrijjkih preduzeća, učinak, finansijska kriza 2008, poslovni modeli, kontrola vlasništva versus ugovorne mreže

JEL Classification: L11, L24, L25, L66, L74 